\title{
Assessing changes in saltwater intrusion in main rivers of Dong Nai province and the adaptive capacity of the communities
}

- Van Bang Nguyen

- Xuan Hoang Tran

Institute of Meteorology Hydrology Oceanology and Environment

- Ngoc Tuan Le

University of Science, VNU-HCM

(Received on $17^{\text {th }}$ December 2015 Accepted on November $21^{\text {th }} 2016$ )

\begin{abstract}
Saltwater intrusion, which is a natural process, is strongly influenced by climate change, and almost negatively affects the lives and livelihoods of communities. This work aims at assessing changes in saltwater intrusion in main rivers located in Dong Nai province. The results indicated that Long Thanh and Nhon Trach districts have been affected by saltwater intrusion with the highest salinity concentrations of about 26-28\%. The salinity level during the dry season is higher than that in the rainy one and the salinity boundaries of $1 \%$ and $4 \%$ gradually extend
\end{abstract}

towards inland water. Besides, adaptive capacity $(A C)$ to saltwater intrusion in Bien Hoa city, Long Thanh and Nhon Trach districts was surveyed and assessed by the AC indices. By assessing AC of local government and communities against 19 criteria, Nhon Trach district showed its high AC meanwhile AC of Long Thanh and other districts were moderate and low, respectively. This research also indicates limitations of each locality, an important basis for proposing solutions to improve $A C$ to saltwater intrusion for the communities.

Keywords: saltwater intrusion, adaptive capacity, adaptive capacity index, climate change

\section{INTRODUCTION}

In the context of climate change (CC), rivers are greatly affected by the fluctuations of temperatures, rainfall, sea levels, etc. including saltwater intrusion (SI). SI alters water quality, as the result, most relevant activities, such as agriculture, farming, aquaculture, services, etc. of the coastal area are impacted. There have been many worldwide studies on SI and SI influences. In Vietnam, researches in this field have begun since 1960s by monitoring salinity in the Red river and Mekong river delta [1]. Dong Nai Province, which is in the Dong Nai - Sai Gon river basin, has high density river and high risk of saltwater intrusion due to being affected by semidiurnal tide in combination with the characteristics of water reserve distribution (20\% in the dry season). From 2007 to 2010, the salinity pervading into Dong Nai river increased significantly [2], which will largely influence socio-economic of Dong Nai Province in general and regions affected by SI in particular. Thence, the study aims at accessing the saltwater intrusion process of main rivers of Dong Nai province (2010-2014) and adaptive capacity to saltwater intrusion of communities by adaptive capacity index method, which provides the basis for vulnerability assessment, constructs appropriate solutions for adaptation, and contributes to ensure the local sustainable development 


\section{METHODS}

Methodological research framework is shown in Fig. 1.

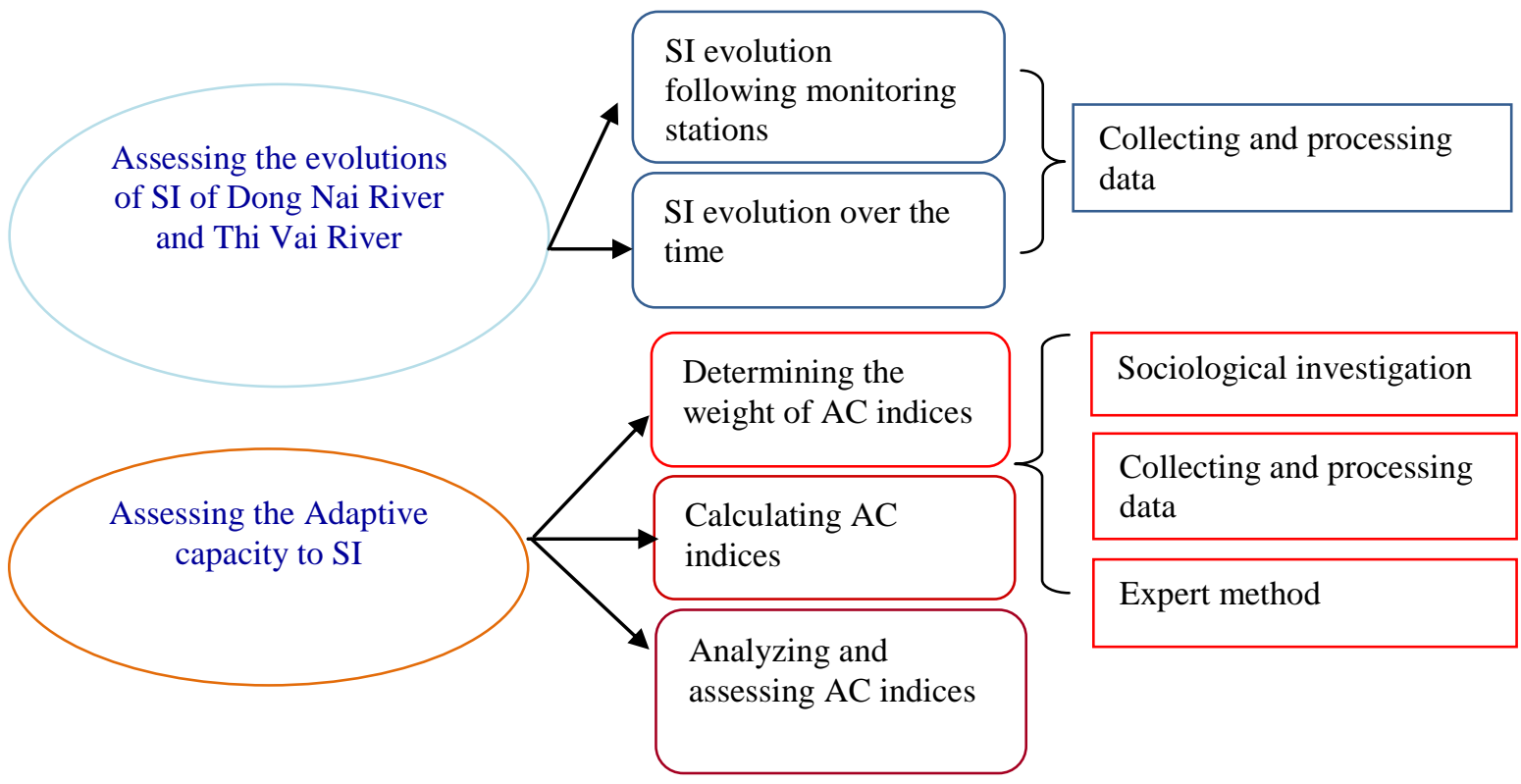

Fig.1. Methodological research framework

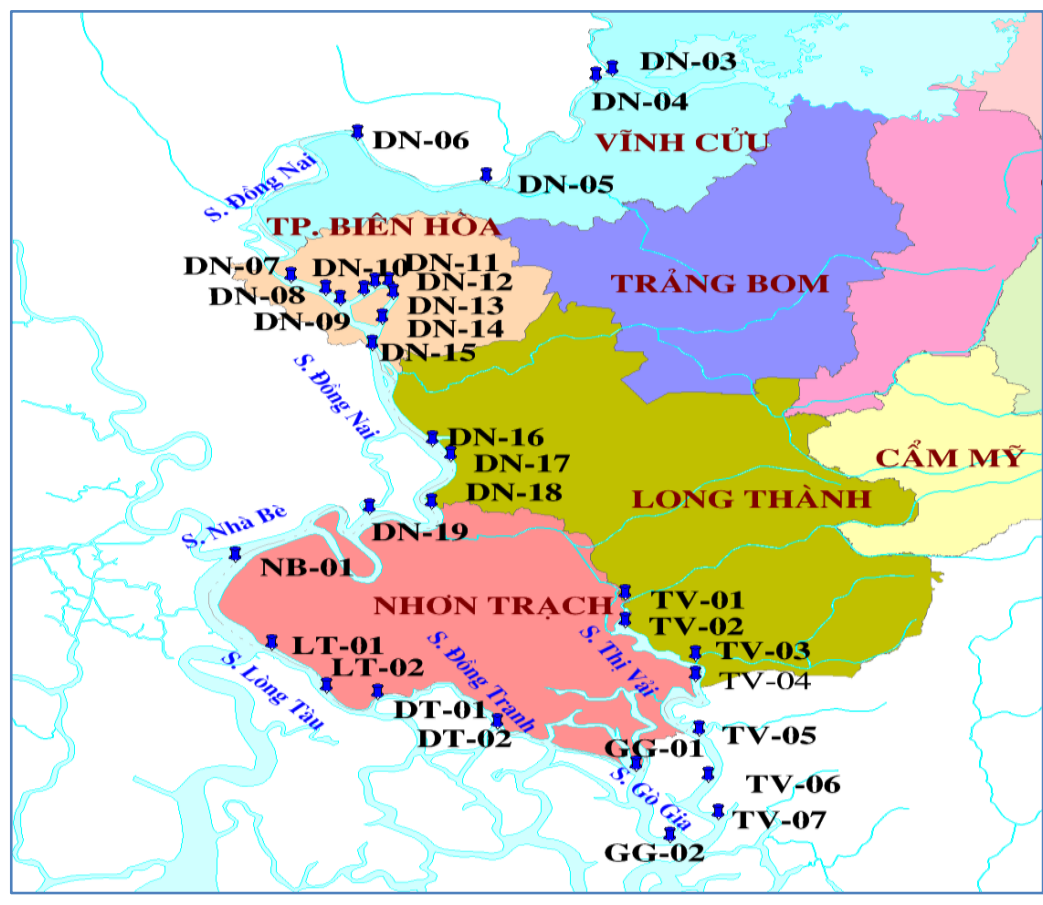

Fig. 2. Salinity monitoring network in Dong Nai river and Thi Vai river [3] 


\section{Data collection method}

It is used for collecting the relevant data to assess the saltwater intrusion process and adaptive capacity. Salinity data were gathered from the Center of Environmental Monitoring and Technique, Dong Nai province. The socioeconomic and environmental data were collected from the Department of Environment and Natural Resources, Department of Agriculture and Rural Development, People's Committees, etc. Salinity monitoring locations in Dong Nai river and Thi Vai river are presented in Fig. 2.

\section{Sociological investigation method}

It was conducted via questionnaires for assessing adaptive capacity to saltwater intrusion of communities, office managers and communalward authorities at Bien Hoa city, Long Thanh and Nhon Trach provinces. The sample size for the communities was based on Yamen's formula (1967 - 1986) with $94 \%$ of the reliability. Therefore, the total sample size was 278 , which was distributed equally to nine wards. For the office managers, the total sample size was 45 (5 officers/ward, 3 surveyed wards/province). For authorities, all 57 People's Committees were surveyed in the research scope.

\section{Expert method}

To improve the adaptive capacity indicators and to determine weight of each criterion, questionnaires were built and 30 experts studying environment, climate change, and saltwater intrusion from many universities, institutes/ research centers were consulted.

\section{Assessing adaptive capacity by indices}

Adaptive capacity is a degree to which the system can decrease damage caused by negative effects of saltwater intrusion or can take advantages of opportunities presented by positive effects [4]. The adaptive capacity to saltwater intrusion depends on many different factors determined by adaptive capacity index (AC). Table 1 demonstrates criteria for assessing adaptive capacity to saltwater intrusion, constructed by literature review and expert methods.

Table 1. Criteria for assessing adaptive capacity to saltwater intrusion

\begin{tabular}{|c|c|c|c|}
\hline Criterion & Notation & Criterion & Notation \\
\hline \multicolumn{2}{|l|}{ Community } & \multicolumn{2}{|l|}{ Local government } \\
\hline $\begin{array}{l}\text { Communities' awareness of climate } \\
\text { change and SI. }\end{array}$ & AC.cd.1 & $\begin{array}{l}\text { The number of staffs taking charge of environmental } \\
\text { resources }\end{array}$ & AC.cq.1 \\
\hline $\begin{array}{l}\text { Ability to access information when } \\
\text { occurring incidents (internet, } \\
\text { cellphone, etc.) }\end{array}$ & AC.cd.2 & Managers' awareness of climate change and SI & AC.cq. 2 \\
\hline $\begin{array}{l}\text { Ability of clean water storage (volume, } \\
\text { time of use, etc.) }\end{array}$ & AC.cd.3 & Programs or plans to support the people in SI field & AC.cq.3 \\
\hline The number of salt-tolerant crop varieties & AC.cd.4 & $\begin{array}{l}\text { The budget for coping with climate change and SI } \\
\text { incidents }\end{array}$ & AC.cq.4 \\
\hline $\begin{array}{l}\text { The proportion of salt-tolerant crop area } \\
\text { /total farmland area }\end{array}$ & AC.cd.5 & The number of salinity monitoring stations & AC.cq. 5 \\
\hline Diversity degree of brackish aquatic & AC.cd.6 & The quantity and quality of salty preventing works & AC.cq. 6 \\
\hline Per capita income & AC.cd.7 & The number (or percentage) of canals dredged annually & AC.cq.7 \\
\hline Education index & AC.cd.8 & $\begin{array}{l}\text { Distance from the considered region to the regulatory } \\
\text { works }\end{array}$ & AC.cq. 8 \\
\hline \multirow[t]{2}{*}{ Proportion of employed workers } & AC.cd.9 & Proportion of health workers / population & AC.cq.9 \\
\hline & & The proportion of teachers / pupils & AC.cq. 10 \\
\hline
\end{tabular}


The criteria have their own scales; hence, it needs normalizing their values from 0 to 100 based on the relationship between the criteria and adaptability [5]. Weights of criteria (group) and component criteria were identified by expert method. Adaptability index was calculated based on the normalized values and the weight of each criterion. Adaptability in each area was assessed by using the scale in Table 2 [6] before being used to establish map of adaptability by GIS.

Table 2. Index-based adaptability assessing scale

\begin{tabular}{|l|l|l|l|l|}
\hline \multicolumn{1}{|c|}{ Value } & \multicolumn{1}{|c|}{$0-25$} & $25-50$ & \multicolumn{1}{|c|}{$50-75$} & $75-100$ \\
\hline Description & Low AC & Medium - Low AC & $\begin{array}{l}\text { Medium - High } \\
\text { AC }\end{array}$ & High AC \\
\hline
\end{tabular}

\section{RESULTS AND DISCUSSION}

Salt intrusion process of Dong Nai river and Thi Vai river

It is obvious that tides in accordance with the ability to shift salinity from Tri An lake have significant influenced on the salinity at monitoring stations. In the $3^{\text {rd }}$ segment of Dong Nai river (SWDN-8，SW-DN-9, SW-DN-10, SW-DN-11, SWDN-12, SW-DN-13, SW-DN-14), the salinity is increasing downstream and tend to increase in the last two years (Fig 3). In 2011, that Dong Nai was affected by drought resulted in the declining salinity shifting capability of the Tri An reservoir, so the average salinity was higher than those of other years. The average salinity of the $3^{\text {rd }}$ segment is under $0.1 \%$, meeting standard of A1-QCVN 08:2008 [7]; therefore, this segment can be used in daily life activities, irrigation, and aquaculture. The 4th segment of Dong Nai river (SW-DN-15, SWDN-16, SW-DN-17) has higher salinity, average value fluctuated between $0.1-2.7 \%$, higher than the standard of B1-QCVN 08:2008. It cannot be used in daily life activities and irrigation.

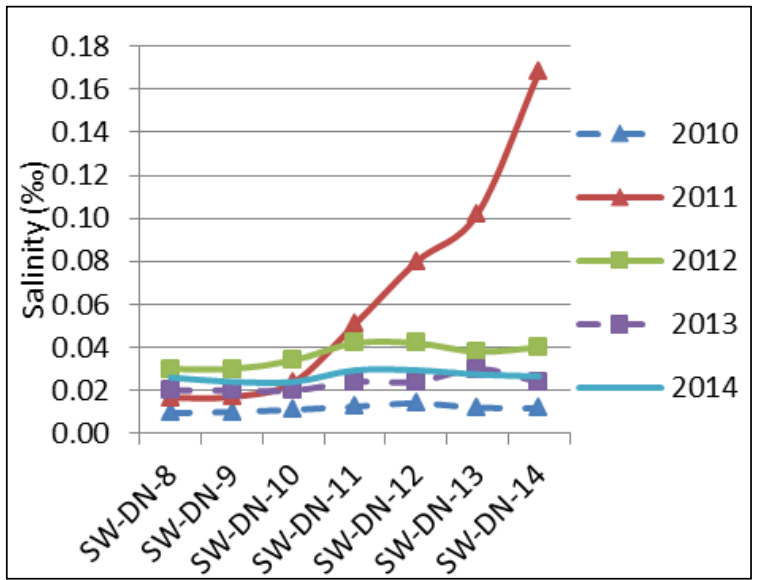

(A)

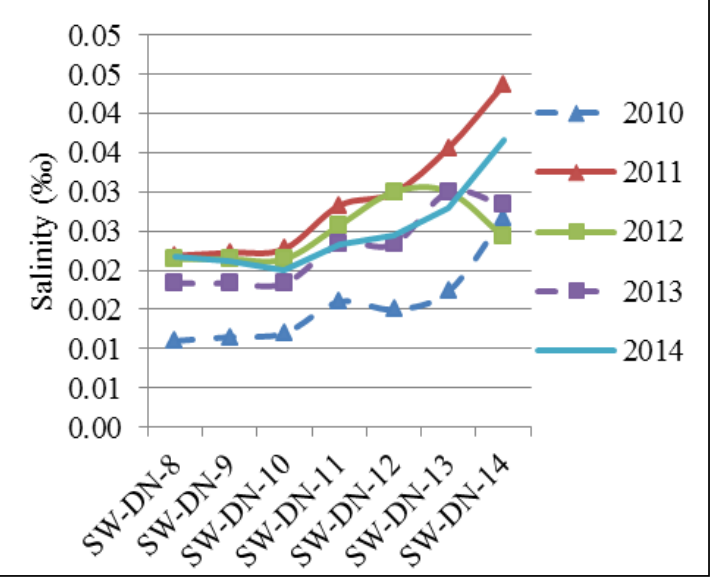

(B)

Fig. 3. Seasonal salinity on Dong Nai river: (A) dry season, (B) rainy season 
Monitoring stations on Thi Vai river (SWTV1, SW-TV2, SW-TV3, SW-TV4, and SW-TV5) have recorded high salinity, annual average value varied from 5.3 to $26.6 \%$. The salinity was increasing downstream (Fig 4). The salinity decreased in the rainy season but not significantly

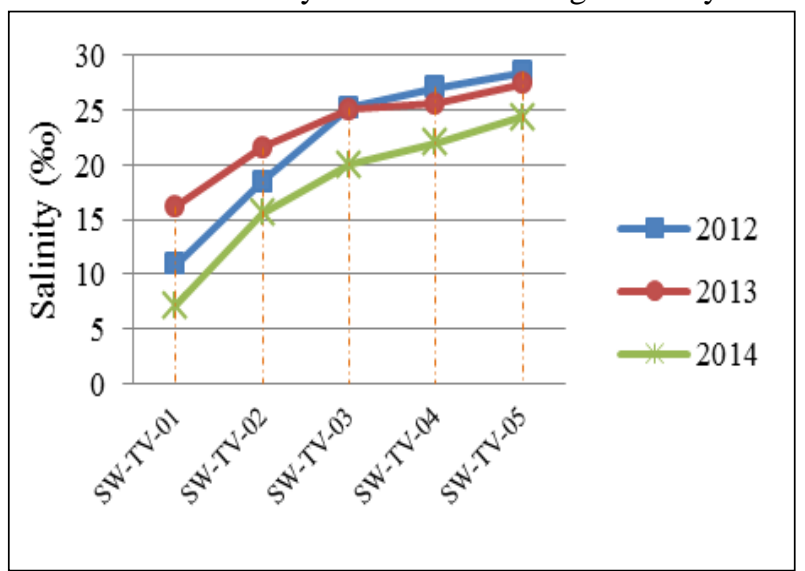

(A) among monitoring stations (2012-2014). According to standard of B1-QCVN-08:2008, with current salinity, Thi Vai river cannot be used for household water supply purposes and agricultural irrigation, resulted in troubles to local citizens.

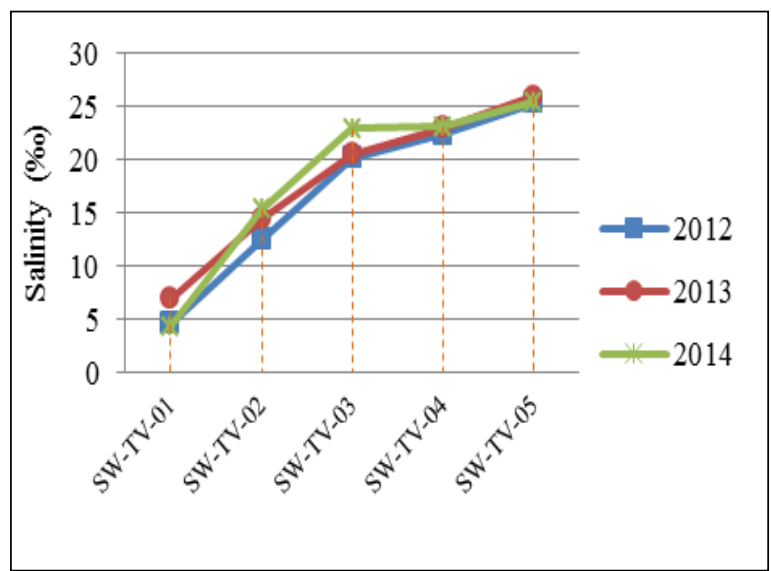

(B)

Fig. 4. Seasonal salinity on Thi Vai river: (A) dry season, (B) rainy season

\section{Assessing salt intrusion adaptability}

Adaptability is accessed based on many factors: quantitative (statistical numbers about officials, income, etc.) and qualitative (such as salt water intrusion awareness in the context of climate change, etc.). Survey results in 3 areas (Bien Hoa city, Long Thanh district, and Nhon Trach district) showed that $76 \%$ of the officials and approximately $64 \%$ of the residents have certain insights of salt intrusion, however, the ratio of those that have full understanding about salt intrusion is very low $(<10 \%)$. On the basis of $\mathrm{AC}$ indicators (Table 1), the relevant data were collected, normalized to 0-100 scale and presented in Table 3.

Table 3. Normalized criteria for official and resident result

\begin{tabular}{|c|c|c|c|c|c|c|c|c|c|c|}
\hline \multicolumn{11}{|c|}{ Local government group } \\
\hline & $\begin{array}{l}\text { AC. } \\
\text { cq. } 1\end{array}$ & $\begin{array}{l}\text { AC. } \\
\text { cq. } 2\end{array}$ & $\begin{array}{l}\text { AC. } \\
\text { cq.3 }\end{array}$ & $\begin{array}{l}\text { AC. } \\
\text { cq. } 4\end{array}$ & $\begin{array}{l}\text { AC. } \\
\text { cq. } 5\end{array}$ & $\begin{array}{l}\text { AC. } \\
\text { cq. } 6\end{array}$ & $\begin{array}{l}\text { AC. } \\
\text { cq. } 7\end{array}$ & $\begin{array}{l}\text { AC. } \\
\text { cq. } 8\end{array}$ & $\begin{array}{l}\text { AC. } \\
\text { cq. } 9\end{array}$ & $\begin{array}{c}\text { AC. } \\
\text { cq. } 10\end{array}$ \\
\hline Bien Hoa & 44.95 & 48.92 & 9.81 & 0.00 & 100.0 & 0.00 & 37.54 & 49.96 & 20.60 & 55.20 \\
\hline Long Thanh & 47.82 & 56.72 & 7.90 & 0.64 & 88.24 & 12.70 & 1.87 & 42.58 & 36.67 & 63.09 \\
\hline Nhon Trach & 46.19 & 55.29 & 22.64 & 9.87 & 55.88 & 100.00 & 100.00 & 10.85 & 35.01 & 67.36 \\
\hline \multicolumn{11}{|c|}{ Residential community group } \\
\hline & $\begin{array}{l}\text { AC. } \\
\text { cd. } 1\end{array}$ & $\begin{array}{l}\text { AC. } \\
\text { cd.2 }\end{array}$ & $\begin{array}{l}\text { AC. } \\
\text { cd. } 3\end{array}$ & $\begin{array}{l}\text { AC. } \\
\text { cd. } 4\end{array}$ & $\begin{array}{l}\text { AC. } \\
\text { cd.5 }\end{array}$ & $\begin{array}{l}\text { AC. } \\
\text { cd. } 6\end{array}$ & $\begin{array}{l}\text { AC. } \\
\text { cd. } 7\end{array}$ & \multicolumn{2}{|c|}{ AC. cd.8 } & AC. cd.9 \\
\hline Bien Hoa & 48.96 & 67.56 & 45.99 & 0.00 & 0.00 & 11.48 & 7.58 & \multicolumn{2}{|l|}{95.81} & 93.92 \\
\hline Long Thanh & 53.63 & 73.97 & 17.22 & 3.88 & 8.79 & 21.01 & 7.42 & \multicolumn{2}{|l|}{95.51} & 92.37 \\
\hline Nhon Trach & 45.11 & 59.33 & 50.51 & 25.81 & 10.06 & 5.39 & 7.50 & \multicolumn{2}{|l|}{95.53} & 97.17 \\
\hline
\end{tabular}


Table 4. Weights of AC indicators

\begin{tabular}{|c|c|c|c|}
\hline \multicolumn{2}{|c|}{ Local government } & \multicolumn{2}{c|}{ Residential community } \\
\hline \multicolumn{2}{|c|}{ Group weight $=0.58$} & Group weight $=0.42$ \\
\hline Indicator & Component weight & Indicator & Component weight \\
\hline AC.cq.1 & 0.073 & AC.cd.1 & 0.171 \\
\hline AC.cq.2 & 0.140 & AC.cd.2 & 0.118 \\
\hline AC.cq.3 & 0.149 & AC.cd.3 & 0.117 \\
\hline AC.cq.4 & 0.137 & AC.cd.4 & 0.106 \\
\hline AC.cq.5 & 0.098 & AC.cd.5 & 0.102 \\
\hline AC.cq.6 & 0.136 & AC.cd.6 & 0.102 \\
\hline AC.cq.7 & 0.072 & AC.cd.7 & 0.109 \\
\hline AC.cq.8 & 0.080 & AC.cd.8 & 0.095 \\
\hline AC.cq.9 & 0.057 & AC.cd.9 & 0.080 \\
\hline AC.cq.10 & 0.057 & \multicolumn{2}{|}{} \\
\hline
\end{tabular}

Applying expert and AHP methods, weights of group criteria and component criteria are identified in relation to the characteristics of the studied area (Table 4).
AC index of each criterion was calculated based on the normalized values (Table 3), component weight of each criterion and group weight (Table 4). The result is presented in Table 5.

Table 5. Saltwater intrusion adaptability index of each indicators

\begin{tabular}{|l|l|l|l|l|l|l|l|l|l|l|}
\hline \multicolumn{1}{|l|}{ Local government group } \\
\hline
\end{tabular}

Then, salt water intrusion adaptability indices are summarized and presented in Table 6. The AC index of three locals are in medium-low level, in which. The Nhon Trach district has the highest adaptability, followed by Long Thanh district and Bien Hoa city. 
Table 6. Saltwater intrusion adaptive capacity index

\begin{tabular}{|c|c|c|c|}
\hline & \multicolumn{1}{|l|}{ Bien Hoa } & Long Thanh & Nhon Trach \\
\hline AC.cq & 32.44 & 32.33 & 48.82 \\
\hline AC.cd & 40.33 & 40.64 & 42.60 \\
\hline AC & 35.75 & 35.82 & 46.21 \\
\hline
\end{tabular}

Each area has its own natural and socioeconomic characteristics; hence, its salt water intrusion adaptability is also different. Nhon Trach has high community awareness of salt intrusion awareness, number and quality of constructions to prevent salinity, and large budget for salinity prevention, etc. Therefore, its adaptability is higher than the rest. Long Thanh has its own strength of high saltwater intrusion community awareness, with programs/plans to prevent salinity, and the diversity of brackish aquatic, etc. Conversely, there still exists some limitations such as poor water storage capacity, limited number of annually dredged canals and salt preventing constructions, low diversity of livelihoods, etc. Bien Hoa has higher number of monitoring stations, livelihoods diversity, and information accessibility than those of Long Thanh and Nhon Trach, though, community awareness of saltwater intrusion is still low. Moreover, being lack of plans/programs to support people in preventing salinity, to build salinity preventing constructions, and to improve small number of salt-tolerant crops and livestock, etc. is its limitation to adapt with the saltwater intrusion.

\section{CONCLUSION}

Assessing result of saltwater intrusion process showed the increase in salinity at monitoring stations on Dong Nai river and Thi Vai river in Dong Nai province during the period of 20102014. Monitoring stations on Dong Nai river recorded the increase in salinity downstream. Saltwater intrusion process on Thi Vai River was the most serious in the province with the highest salinity level (>30\%o, 2012).

Saltwater intrusion $\mathrm{AC}$ assessed by indices indicated that Nhon Trach district has the highest adaptability, followed by Long Thanh district and Bien Hoa city. These three investigated locals are in the range of medium-low AC level. Some factors, such as officials' and residential community's low awareness of saltwater intrusion, the poor quantity and quality of salinity preventing constructions as well as weak supporting solutions from the government have resulted in their limited adaptability to saltwater intrusion. 


\section{Đánh giá diễn biến xâm nhập mặn trên các sông chính của tỉnh Đồng Nai và năng lực thích ứng với của cộng đồng cư dân}

- Nguyễn Văn Bằng

- Trần Xuân Hoàng

Viện Khí tượng Thủy văn Hải văn và Môi trường

- Lê Ngọc Tuấn

Trường Đại học Khoa học Tự nhiên, ĐHQG-HCM

\section{TÓM TẮT}

Xâm nhập mặn (XNM) là một quá trình tư nhiên, chịu ảnh huơong mạnh của biến đổi khi hậu, hầu nhu ảnh hưởng tiêu cực đến đời sống và sinh kế của cộng đồng. Nghiên cưu nhằm muc tiêu đánh giá diễn biến XNM trên các sông chinh ở tỉnh Đồng Nai. Kết quả cho thấy, huyện Long Thành và huyện Nhơn Trạch đang chịu tác động của XNM với độ mặn cao nhất dao động tù 26-28\%. Độ mặn mùa khô cao hơn mùa mua với ranh mặn $1 \%$ và 4\% ngày càng lấn sâu vào nội tỉnh. Bên cạnh đó, năng lục thich ưng với XNM tại thành phố Biên Hòa, Huyện Long Thành và Nhơn Trach đurợc

Tù khóa: xâm nhập mặn, khả năng thích ưng, chỉ số khả năng thích ứng, biến đổi khí hậu

\section{REFERENCES}

[1]. S.H. Duong Surface water's salt intrusion prediction research in Nam Dinh province. Hanoi University of Water Resources (2012).

[2]. Department of Natural Resources and Environmentof Dong Nai province, Center of Environmental Engineering and Monitoring General report on quality of aquatic environment monitoring mission of Dong Nai river in Dong Nai province (2010).

[3]. Department of Natural Resources and Environmentof Dong Nai Province, Center of Environmental Engineering and Monitoring Monitoring result of aquatic environment quality of Dong Nai river, Thi Vai river and their tributaries (2010-2014). khảo sát, đánh giá thông qua bộ chỉ thị khả năng thich ứng. Trên cơ sở đánh giá khả năng thich ưng với XNM của chính quyền địa phuoong và công đồng dân cu thông qua 19 chỉ thị, cho thấy huyện Nhon Trach năng lục thích úng với XNM cao nhất, tiếp đó là Long Thành và Biên Hòa. Cả ba huyện thành này đều có mức thich ứng trung bình thấp. Nghiên cứu cũng chỉ ra các khiếm khuyết của tùng địa phuoong - là co sở để đề xuất các giải pháp nâng cao năng lục thich úng với XNM cho cộng đồng.

[4]. Intergovernmental Panel on Climate Change (IPCC) - Climate Change: Impacts, Adaptation and Vulnerability (2007).

[5]. C.T. Van, N.T. Son, Vulnerability indexes and calculation methods. Proceedings of the annual scientific conference -Sub-Institute of Hydrometeorology and Environment of South Vietnam (2012).

[6]. Local Government Association of South Australia, Guidelines for developing a climate change adaptation plan and undertaking an integrated climate change vulnerability assessment 41 (11-2012).

[7]. Ministry of Natural Resources and Environment - QCVN 08:2008/BTNMT, National Technical Regulation on surface water quality. 